\title{
Manuscript Details
}

\section{Manuscript number}

Title
YCRES_2019_205

Vegetation of the Late Cretaceous vertebrate site of Chera (Valencia, Spain) and its significance in mosaic vegetation from southwestern Europe.

Full Length Article

\section{Article type}

Abstract

A palynological analysis of the Late Cretaceous vertebrate sites of Chera (Valencia, Spain) has been carried out. The occurrence of diversified Normapolles including various species of Vancampopollenites Papillopollis and Pseudoromeinipollenites suggest a late Campanian/?early Maachtrichtian age. The inferred assemblages indicate an azonal vegetation involving peat-mosses, sedges and palms colonizing wetlands with ephemeral or semi-permanent pools and lakes. The abundant and diverse Normapolles reflect the regional presence of woodlands or other open vegetation types with prominent Fagales. The integration of Chera pollen assemblages with contemporaneous palynological and paleobotanical data from SW Europe indicates the co-existence of numerous, structurally different and taxonomically individualized plant communities. The inferred paleofloral heterogeneity is compatible with the current paleogeographical reconstructions of SW Europe and probably enhance the appearance of the highly diverse fauna with insular characteristics of the latter part of the Late Cretaceous.

\section{Keywords}

Taxonomy

Corresponding Author

Corresponding Author's Institution

Order of Authors

Suggested reviewers

\section{Normampolles; Fagales; France; Late Cretaceous;Chera}

Earth History, Geology, Biogeoscience

Daniel Peyrot

The University of Western Australia

Daniel Peyrot, Eduardo Barrón, Xabier Pereda-Suberbiola, Julio Company

Ulrich Heimhofer, Zélia Pereira, James A. Doyle

\section{Submission Files Included in this PDF}

File Name [File Type]

Chera_Draft_20190618.doc [Manuscript File]

Figura 1 final V1.jpg [Figure]

CH_fig_2new.jpg [Figure]

$\mathrm{CH}_{-}$fig4new.jpg [Figure]

CH_Fig5newJune2.jpg [Figure]

$\mathrm{CH}$ _fig6new.jpg [Figure]

\section{Submission Files Not Included in this PDF}

\section{File Name [File Type]}

CH_Fig3newJune2019.png [Figure]

Chera_Table_1n.xlsx [Table]

To view all the submission files, including those not included in the PDF, click on the manuscript title on your EVISE Homepage, then click 'Download zip file'. 


\section{Research Data Related to this Submission}

Data set

https://data.mendeley.com/datasets/6dbz6pgzwb/draft?a=06c86dfd-8a2c-4410bfad-44da88612bb0

Data for: Vegetation of the Late Cretaceous vertebrate site of Chera (Valencia, Spain) and its significance in mosaic vegetation from southwestern Europe.

Palynological counts of the Chera vertebrate site 


\title{
Vegetation of the Late Cretaceous vertebrate site of Chera (Valencia, Spain)
} and its significance in mosaic vegetation from southwestern Europe.

\author{
Daniel Peyrot ${ }^{1 *}$, Eduardo Barrón ${ }^{2}$, Xabier Pereda-Suberbiola, X. ${ }^{3}$, Julio Company ${ }^{4}$ \\ ${ }^{1}$ School of Earth and Environment, University of Western Australia. 6101 Crawley, Western \\ Australia. daniel.peyrot@uwa.edu.au, *corresponding autor. \\ 2 Museo Geominero, Instituto Geológico y Minero de España, Ríos Rosas 23, 28003 Madrid, Spain. \\ ${ }^{3}$ Universidad del País Vasco/Euskal Herriko Unibertsitatea, Facultad de Ciencia y Tecnología, \\ Departamento de Estratigrafía y Paleontología, Apartado 644, 48080 Bilbao, Spain \\ ${ }^{4}$ Universidad Politécnica de Valencia, Departamento de Ingeniería del Terreno, 46022 Valencia, Spain.
}

\begin{abstract}
A palynological analysis of the Late Cretaceous vertebrate sites of Chera (Valencia, Spain) has been carried out. The occurrence of diversified Normapolles including various species of Vancampopollenites Papillopollis and Pseudoromeinipollenites suggest a late Campanian/?early Maachtrichtian age. The inferred assemblages indicate an azonal vegetation involving peat-mosses, sedges and palms colonizing wetlands with ephemeral or semi-permanent pools and lakes. The abundant and diverse Normapolles reflect the regional presence of woodlands or other open vegetation types with prominent Fagales. The integration of Chera pollen assemblages with contemporaneous palynological and paleobotanical data from SW Europe indicates the co-existence of numerous, structurally different and taxonomically individualized plant communities. The inferred paleofloral heterogeneity is compatible with the current paleogeographical reconstructions of SW Europe and probably enhance the appearance of the highly diverse fauna with insular characteristics of the latter part of the Late Cretaceous.
\end{abstract}

\section{Introduction}

The Cretaceous Period is characterized by a drastic change in vegetation and the advent of plant communities including prominent flowering plants. The transition from coniferto angiosperm-dominated ecosystems has been gradual and varied dramatically across geographical areas (Crane and Lidgard, 1989; Peyrot et al., 2008; Friis et al., 2011; Korasidis et al., 2016; Heimhofer et al., 2018). During the Late Cretaceous, a significant part of Northern Hemisphere was covered by vegetation involving wind-pollinated angiosperms related to Fagales and producing pollen grains with complex apertures called Normapolles (Vakhrameev, 1991). During the latter part of this period, 
Normapolles-producers reached high diversity and often formed the dominant component of open vegetation types covering vast expanses of Western Europe (Batten, 1986a; Peyrot et al., 2013). The distinctiveness of Campanian-Maastrichtian pollen assemblages recovered from Portugal and Spain prompted various authors to recognize Iberia as a separate paleobiogeographic province (Batten and Li, 1987; Herngreen et al., 1996) and suggests high levels of endemism probably related with the fragmented nature of emerged lands (Smith et al., 1994; Seton et al., 2009; Handy et al., 2010). In spite of constituting the main framework of terrestrial ecosystems where prodigiously diverse fauna evolved and thrived (Csiki-Sava et al., 2015; Ortega et al., 2015; PeredaSuberbiola et al., 2015), the structure and composition of Late Cretaceous European and Iberian plant communities remain poorly characterized (Diéguez et al., 2010). The present study presents a palynological analysis, new biostratigraphic data, vegetation reconstruction and vertebrate inventory of the Late Cretaceous site of Chera (Valencia, Spain) and compare them with floral data from other coetaneous locations of Western Europe.

\section{Geological settings}

The Chera Basin is well-known to host one of the richest Late Cretaceous vertebrate outcrops of Iberia (Company et al. 2005, 2009a; Company, 2004, 2011; Company and Szentesi, 2012). It is located in the southwestern Iberian Range (Valencia province, Eastern Spain) and includes numerous fossiliferous localities which yield diverse vertebrate assemblages (see e.g., Company, 2004; Company and Szentesi, 2012). The studied outcrops are characterized by a rich vertebrate assemblage including dinosaurs (Rhabdodon, Struthiosaurus, Lirainosaurus, maniraptoran and abelisauroid theropods), pterosaurs and microvertebrate remains of aquatic and semi-aquatic organisms such as bony fishes, amphibians and squamates (Company, 2004; Company et al., 2009b). Chelonians (Solemys, Polysternon and Dortoka) and crocodilians (Acynodon, Musturzabalsuchus, Doratodon) represented the most diverse recorded faunal groups. Preliminar palynological studies suggested a high diversity of Normapolles-types and a great abundance of sphagnaceous spores and freshwater algae (Peyrot et al., 2009).

The material described herein was collected from several exposures of the Sierra Perenchiza Formation in the Chera Basin (southwestern Iberian Range, Valencia 
Province, Spain), approximately $2 \mathrm{~km}$ south of the village of Chera (Fig. 1). The formation is a continental, shallow-water carbonate unit dated as late Campanian/early Maastrichtian (Vilas et al., 1982; Garcia et al., 2004; Pueyo et al., 2014) and outcrops in the southeastern margin of the Iberian Range, where it reaches a maximum thickness of about $50 \mathrm{~m}$. It consists of lagoonal micritic and brecciated limestones, grading upwards to palustrine carbonates with evidence of pedogenic modifications including rooting, mottling and pseudomicrokarst (Platt, 1989; Alonso et al., 1991). The lower part of the Sierra Perenchiza Formation consists mainly in medium to thick-bedded brecciated limestones and yield a biota including gastropods (Pyrgulifera armata, Potamididae, Ellobiidae) and ostracods (Cyprididae) suggesting depositional settings in shallow and low-salinity waterbodies (Platt and Wright, 1992). Oligohaline conditions are also supported by the presence of the charophytes Amblyochara, Peckichara and Platychara (Company, 2004). The upper part of the unit is mainly represented by interbedded marls and limestones interpreted to represent small, coastal, ephemeral, carbonate lakes and ponds. The pedogenic structures occurring in this interval indicate subaerial exposures suggesting fluctuations of water table which have been linked to episodic or seasonal aridity (Company, 2004).

\section{Material and methods}

Two detailed stratigraphic sections of the upper part of the Sierra Perenchiza Formation were logged in the study area. The sections were measured in the Barranco del Agua Creek and in La Castellana Creek. Samples labelled as $\mathrm{CH}$ - were collected from the Barranco del Agua exposures, whereas the samples labelled LC come from the La Castellana site (Fig. 1). The first section corresponds to one of the parastratotypes of the Sierra Perenchiza Fm. (Vilas et al., 1982) and presents a thickness of about $50 \mathrm{~m}$. The exposures are characterized by a succession of dark grey, green, white, and pink marls intercalated with limestone lenses. Up to 7 samples have been collected form the marls (Fig. 1). Four of them were barren, and only two of the sampled levels produced palynomorphs (CH-I-4 and CH-III-1b).

- Sample CH-I-4 has been collected from a thick, massive, dark grey, mudstone containing abundant vertebrate remains. This bed provided the richest vertebrate 
assemblage of the formation and is the type locality of the ziphodont crocodyliform Doratodon ibericus (Company et al., 2005). The faunal assemblage also includes gastropods and bivalves and is accompanied by abundant carbonized plant remains and charophytes.

- Sample CH-III-1b comes from a narrow dark clay lens interbedded between palustrine limestones with abundant root traces and strong pedogenic modifications. This level has produced gastropods, ostracods, abundant micro-remains of bony fish, amphibians and charophytes.

In La Castellana Creek, ravine incision has produced extremely good exposures of the upper part Sierra Perenchiza Formation. All soft horizons in a 30 meters-thick section were systematically sampled, but only one of them produced palynomorphs: LC-I-5 was collected for a narrow grey level intercalated between couplets of palustrine limestones.

The samples were prepared following standard palynological processing techniques, involving $\mathrm{HCl}$ and $\mathrm{HF}$ treatments and excluding any oxidative maceration in order not to degrade delicate palynomorphs (Batten, 1999). Photographs of the more representative taxa (Figs. 2, 4-5) were taken using a Color View Illu camera coupled to an Olympus BX51 microscope. Confocal laser scanning microscopy was employed to characterize several specimens using the methodology explained in Peyrot et al. (2007). A palynofloral list of the taxa recovered and organized according to known, inferred or supposed botanical affinities is presented in Table 1 .

\section{Results}

\subsection{Assemblage description}

The palynomorphs presented a fairly good preservation and a light colour suggesting low thermal maturation (Batten, 1996a). The assemblages yielded more than 83 types of palynomorphs (Table 1), mainly consisting of angiosperm pollen grains (42 taxa), bryophyte and pteridophyte spores (24 taxa) and gymnosperm pollen grains (7 taxa). Palynomorphs with a presumed marine origin include dinoflagellate specimens attributed to Spinidinium (Figs. 2A-C) and have been recorded in only one sample (CHI-4). Freshwater palynomorphs are relatively diverse (8 taxa) and observed in all the 
productive samples. These include coenobia of Botryococcus spp. (Fig. 2D) and resting cysts attributed to Ovoidites spriggii (Fig. 2E), Ovoidites cf. ligneolus (Fig. 2F), Ovoidites spp. (Fig. 2G), Tetranguladinium conspicum (Fig. 2H), Protoellipsodinium fibratum (Figs. 2L-M) and Spicadinium cf. akidoton (Fig. 2N-O). Freshwater algae reach numerical significance ( $8 \%$ of the total assemblage, Fig. 3) in one sample $(\mathrm{CH}-$ III-1b) and are only sporadically observed elsewhere.

Spores represent between 20\% (CH-III-1b) and 45\% (CH-I-1) of the counted palynomorphs (Fig. 3). The most frequently occurring taxa include the fern spores with uncertain affinities Gabonisporis vigourouxii (Fig. 4G) and G. cristatus (Fig. 4H) as well as representatives of Cyatheaceae/Dicksoniaceae (Deltoidospora spp., Biretisporites cf. potoniei, Fig. 4A), presumed Anemiaceae (Ischyosporites spp., Fig. 4E) and Polypodiaceae. Other spore-producers are poorly represented. Lycopsids include three taxa, and liverworts are only represented by the species Zlivisporis reticulatus (Fig. 4C). The level $\mathrm{CH}-\mathrm{III}-1 \mathrm{~b}$, however, includes a substantial amount of presumed sphagnaceaen taxa including specimens herein referred to Acanthotriletes? trigonus (Figs. 4J-K), Cingulatisporites levispeciosus (Fig. 4D) and Cingulatisporites spp.

Gymnosperms are not diverse and only represent a subordinate component of the assemblages (c. 5\%, Fig. 3). Bisaccate pollen are uncommon and the bulk of gymnosperms is constituted by polyplicate grains of the species Equisetosporites multicostatus (Fig. 5A) and E. patapscoensis (Fig. 5B), presumably related to Gnetales.

Conversely, angiosperms are diverse and quantitatively predominant (Fig. 3). In CH-III$1 \mathrm{~b}$, flowering plants account for $65 \%$ of the total palynomorphs, the most frequently occurring taxa being Penetetrapites inconspicuous (Fig. 5C) and two taxa assigned to the genus Monocolpopollenites (Figs. 5G-I). Fagales are diverse and represent between $6 \%$ (CH-III-1b) and 26\% (LC-I-5) of the assemblages (Fig. 3). The most common taxa include Papillopollis spp. (Figs. 5M-N), Trudopollis spp. (Figs. 5K-L, 5Q), Vacuopollis spp. (Figs. 5AA-5AB), Vancampopollenites spp. (Figs. 5AD-5AE) and grains related to the Betulaceae (Interporopollenites spp., Figs. 6B-C). These pollen, commonly recorded in Late Cretaceous palynofloral assemblages from Western Europe but uncommon or absent in eastern North America, are also accompanied by rarer 
forms, such as Pseudoromeinipollenites laevigatus new comb. (Appendix 1; Fig. 5O),

173 Tricolpites synstriatus (Fig. 6J) and specimens described herein and referred to as Vancampopollenites? sp. 1 (Appendix 1; Figs. 6D-I).

While the three assemblages from Chera are taxonomically similar (Fig. 3), they can be ordered according to their content in freshwater palynomorphs plus presumed hygrophytes: (i) CH-III-1b presents a typical lacustrine signal with a high content in freshwater algae and spores produced by plants presumably related moist and humid environments; (ii) CH-I-4 shows a much lower content in freshwater palynomorphs and still includes a conspicuous proportion of spores; (iii) LC-I-5, conversely, does not yield any significant input from freshwater palynomorphs. The palynofloral association of this level includes, however, dinoflagellate cysts and a higher number of Normapolles (Fig. 3).

\subsection{Selected taxonomy}

Pseudoromeinipollenites Kedves in Kedves \& Russell, 1982 emend. Legoux, 1986

type species: Pseudoromeinipollenites paleocenicus Kedves in Kedves \& Russell, 1982, p. 98, P1. 7, Figs. 21-22, Text-fig. 1

\section{Pseudoromeinipollenites laevigatus new comb. (Fig. 5O)}

syn. Romeinipollenites laevigatus Kedves \& Herngreen, 1980, p. 517-518; P1. 9, Figs. 1-2

syn. Polaroporis sp. 2 Médus, 1981, p. 22; P1. 9, Figs. 1-3, 6

syn. Pseudoromeinipollenites aquitanensis Legoux, 1986, p. 415; P1. 1, Figs. 1-3

Description: Small-size, breviaxial, planaperturate pollen grains with a circular to rounded-triangular equatorial outline. Mostly strutureless and unornamented exine. Nexine of equal thickness, sexine thicker in apertural regions defining inconspicuous (i.e., not protruding) ektannuli. Exoapertures are vertical slits widening towards polar areas, endoapertures circular with ragged margins and located in subequatorial position, atria not developed.

Remarks: The transfer of Romeinipollenites laevigatus to the genus Hungaropollis proposed by Polette and Batten (2017) is not followed. The circular endoaperture mentioned in the diagnosis and apparent in illustration of the holotype (Kedves \& 
205 Herngreen, 1980, p. 517-518, P1. 9, Fig. 2) suggests an attribution to the genus

206 Pseudoromeinipollenites Kedves, 1982 emend Legoux, 1986.

Vancampopollenites Kedves \& Pittau, 1979

type species: Vancampopollenites lusitanus Kedves \& Pittau, 1979, p. 202, P1. 7, Figs. $1-3$

Description: Pollen oblate with a square rounded outline in polar view. Exine 8-12 $\mu \mathrm{m}-$ thick except in polar areas. Nexine much thinner than sexine. Four complex apertures consisting in 15-20 $\mu \mathrm{m}$-long colpi and, protruding, c. $5 \mu \mathrm{m}$-wide pori with ragged margins. Endogerminal characteristics not apparent.

Remarks: The polar exinal thinning relates the specimens to the genus Vancampopollenites Kedves \& Pittau, 1969. The protruding nature of pori prevents an unquestionable generic attribution.

\section{Discussion}

\subsection{Palynology-based biostratigraphy}

The faunal assemblage of Chera includes abundant dinosaur remains attributed to Rhabdodon, Struthiosaurus and Lirainosaurus, as well as chelonian like solemydids and dortokids and crocodilian taxa such as Acynodon, Musturzabalsuchus and Doratodon (Company, 2004). This indicates that the vertebrate macrofauna of Chera is very similar to that of Laño (Condado de Treviño), which is considered as representative of the late Campanian of the Iberian Peninsula (Pereda-Suberbiola et al., 2015; Corral et al., 2016). Late Cretaceous terrestrial palynological assemblages from Western Europe are notoriously difficult to correlate due to the paucity of successions with independent calibration (Herngreen et al., 1986; Méon et al., 2001) and the great number of pollen taxa inadequately described or with a stratigraphic range poorly understood (Batten and Morrison, 1987; Batten et al., 1988). The presence of numerous 'complex' types of Normapolles including Vancampopollenites spp. (Fig. 5AD-AE) and Papillopollis spp. are suggesting an age not older than Campanian (Batten, 1986a; Batten and Morrison, 1987). A slightly younger age is suggested by the single specimen of Tricolpites synstriatus recorded in CH-III-1b as this species appears with relative frequency in 
Maastrichtian assemblages of Bolivia (Vajda-Santivanez, 1999), Brazil (Regali et al.,

240 1974a, 1974b), Senegal (Jardiné and Magloire, 1965) and Western USA (Farabee and

241 Canright, 1986). The presence of Pseudoromeinipollenites laevigatus new comb. (Fig. $5 \mathrm{~N}-\mathrm{O})$ suggests an early - early late Maastrichtian age as this species has been recorded in Lixhe 3 of the the Gulpen Formation, Netherlands (Kedves and Herngreen, 1980) and in strata dated as Maastrichtian from W and SW France (Médus, 1981; Legoux, 1986) and Spain (Médus, 1987). This interpretation should be considered with caution given the inconsistent (i.e., rare) distribution of the mentioned species. Conversely, the presence of abundant Gabonisporites vigourouxii (Fig. 4G) and Penetetrapites inconspicuous (Fig. 5C) may relate the palynofloras of Chera with the assemblages from the Maastrichtian Aquilapollenites-Penetetrapites Assemblage Zone described in Korea (Yi and Batten, 2002; Yi et al. 2003). G. vigourouxii did not reach numerical significance until the Maastrichtian in North Africa (Méon, 1991; Shrank, 1994) and Bolivia (Vajda-Santivanez, 1999). It seems, however, likely that Penetetrapites and G. vigourouxii reflect more local hygrophytic vegetation and present a biased stratigraphic distribution (see Paleovegetation section). Altogether, the palynological assemblages does not allow to reach a conclusive age and a conservative late Campanian/?early Maastrichtian in line with macrofaunal data is adopted.

\subsection{Paleovegetation}

\subsubsection{Local wetland environment of Chera}

The presence of freshwater algae in association with abundant Marsileaceae (Gabonisporis spp.; Fig. 4G-I) allow to infer the presence of wetlands with ephemeral or semi-permanent pools and lakes colonized by aquatic or semi-aquatic sporeproducers. The high number of spores presumably affiliated to Sphagnaceae recorded in CH-III-1b (Acanthotriletes? trigonous, Cingulatisporites levispeciosus, Cingulatisporites spp., Stereisporites steroides; Fig. 4D, J-K) supports this hypothesis and also suggests the presence of peat-forming environments. Modern Sphagnaceae are mosses sensitive to desiccation and are frequently observed in water-logged, nutrientpoor habitats (Alpert, 2005). These hygrophytic communities also included angiosperms producing Penetetrapites inconspicuus (Fig. 5C) and related to Cyperaceae (Sweet, 1986). If this interpretation is correct, the palynoflora of Chera would represent one of the oldest wetlands typified by abundant peat-mosses and sedges. The substantial 
number of monocolpate grains may reflect the presence of parautochthonous palms in the azonal vegetation. These could have been quantitatively important in the driest, or episodically or seasonally aerated, habitats bordering the water-logged environments. The low number of morphotypes (e.g. only three monoaperturate grain types, Figs. 5DE, G-I) suggest, however, that palms formed low-diversity vegetational stands.

5.2.2. The presence of Normapolles in Chera and their significance in Late Cretaceous floras of Iberia

The assemblages of Chera include diverse and abundant (per-)oblate pollen with complex apertures assigned to the Normapolles complex (Góczán et al., 1967; Batten and Christopher, 1981; Fig. 5K-O, Q-S, X-Z, AA-AE, AI; Fig. 6B-C). Their presence in most Upper Cretaceous assemblages has long been recognised and allowed to define the eponymous paleobiogeographic province covering eastern North America, Western Europe (excluding northern Scandinavia) and West Siberia (Batten, 1984; Herngreen et al., 1996 and reference therein). While the western and eastern boundaries of the province were delineated by epicontinental seas, the latitudinal expanse of the province (roughly $20-40^{\circ} \mathrm{N}$ ) probably corresponded to climatic boundaries. Variations in climate have also been invoked to explain the marked differences in Normapolles composition between Iberia, Western Europe and North America (Goczán et al., 1967; Kedves, 1985; Batten and Li, 1987). The morpho-functional analysis of Normapolle grains from upper Cretaceous strata from Aveiro (Portugal) allowed Batten (1986a, 1986b) to suggest (seasonally) seasonal or semi-arid climatic conditions for Iberia.

In Chera, Normapolles outnumbers other angiosperms and represent $60 \%$ of the diversity of flowering plants (19 taxa including three informal species and seven generically attributed but binomially undesignated; Appendix 1). While Normapolles constituted still a significant proportion of Paleocene palynofloras from western USA and Western Europe, their abundance and diversity decreased subsequently and the group became extinct by the end of the Eocene (Gruas-Cavagnetto, 1968; Kedves \& Russell, 1982; Ollivier-Pierre et al., 1987; Frederiksen, 1995). The replacement of Normapolles by pollen morphologically more akin to those produced by modern members of Fagales (e.g., Momipites, Caryapollenites) started during the Maastrichtian 
and intensified during the Paleogene. In Iberia, Fagales represented a significant component of palynofloras during the Neogene (e.g., 38 and 18 pollen species were respectively recorded in the Oligocene of NW Spain and the late Miocene of SE Pyrenees; Barrón et al., 2016, Casas-Gallego, 2018). Modern representatives are dispatched in eight families (Angiosperm Phylogeny Group, 2016) mainly distributed in the Northern Hemisphere, where they constitute the principal elements of the temperate and cool/cold deciduous and mixed forests. With few exceptions, the majority of modern members are anemophilous and shed abundant pollen, usually well-preserved in sediments. Often, several species coexist in the same ecosystems (see e.g., Quézel et al., 1980; Assadollahi et al., 1982; Morin, 1997; Costa Tenorio et al., 2005), but usually inhabit different ecological niches (e.g., sunny or shadow places, humid or dry soils, colder or hotter microclimates, etc.) or present different physiognomies (tree- vs shrubhabit). The Normapolles-producers from the latter part of the Late Cretaceous were likely wind-pollinated shrubs or tree-size plants (Batten, 1986a; Friis et al., 2011) but probably also included few, lower stature taxa. By analogy with extant forested communities incorporating Fagales, Normapolles-producing plants were likely colonizing dry hinterland settings or moister river border and constituted or formed part of open forests (i.e. forest or woodlands) or riparian vegetation.

In Chera, the Normapolles abundance varies according to the sample considered. In CH-III-1b, their reduced abundance (Fig. 3) suggests the absence or poor representation of wind-pollinated Fagales in the vegetation close to the site of deposition. Alternatively (but not exclusively), this signal, together with the low representation of bisaccate pollen, could reflect a small-size depositional setting surrounded by closed vegetation preventing the influx of regional, air-borne, palynomorphs (Jacobson and Bradshaw, 1981). The increase in Normapolles observed in CH-I-4 and LC-I-5 (Fig. 3) is interpreted to reflect a more open vegetation.

Collectively, the pollen assemblages of Chera indicate the presence of regionally extended woodlands incorporating diversified Normapolle-producers and conifers (levels CH-I-4 and LC-I-5), hosting episodical (or seasonal) wetlands characterized by peat mosses, sedges and palm trees (level CH-III-1b). The record of several specimens of dinocyst in LC-I-5 is significant as it implies a marine incursion and brackish environment related to a coastal depositional setting. 
Upper Cretaceous assemblages from Spain may be grouped according to their content in Normapolles. The high diversity and abundance of these pollen recorded in CH-I-4 and LC-I-5 have also been described in other Campanian-Maastrichtian strata from the

Iberian Peninsula: Sedano in Burgos province (Médus, 1987), Barranco de la Posa in the South-Cental Pyrenees (de Porta et al., 1985; Ashraf and Erben, 1986) and the upper part of the Fontllonga succession, in the Tremp Basin (Médus et al., 1988, 1992; Mayr et al., 1999; Fernández-Marrón et al., 2004). In Sedano, Médus (1987) distinguished various plant communities and suggested the existence of lagoonal wetlands with Typhaceae/Sparganiaceae similar to the ones described at the vertebrate site of Lo Hueco (Peyrot et al., 2013). The younger Fontllonga succession spans the CretaceousCenozoic transition and records higher number of Normapolles in the Danian interval (Mayr et al., 1999; Fernández-Marrón et al., 2004). In this succession, the presence of boreal elements (Aquilapollenites) could indicate ecological disturbance triggered by short-lived climate degradation. The lower Maastrichtian assemblages of Barranco de la Posa include diversified Normapolles in association with more evolved Fagalean pollen (e.g. presumed Juglandaceae Platycaryapollenites) but is numerically dominated by monocolpate and inaperturate pollen grains (de Porta et al., 1985; Ashraf and Erben, 1986). Collectively, the data from Barranco de la Posa indicates a flora incorporating Fagales and palm trees as in Chera but with a higher proportion of cypresses suggesting slightly drier environments.

The lower abundance of Normapolles in CH-III-1b relates this level with the palynoflora of Lo Hueco, central Spain (Peyrot et al. 2013) and the assemblages from Isona, Fígols-Vallcebre, Campo and the lower part of the Fontllonga succession (Mayr et al., 1999; Fernández-Marrón et al., 2004; Villalba-Breva et al., 2015). The difference between Chera and Lo Hueco is likely to reflect a biostratinomic bias, the assemblages of the latter representing a more restricted pollen source area (Peyrot et al., 2013). The late Maastrichtian locality of Molí de Baró-1 (southeastern Pyrenees) does not include Normapolles but pollen of more evolved morphologies with Juglandacean affinities (Marmi et al., 2015). This record is interesting as it suggests local arborescent communities where Normapolles-producers have been replaced by their modern counterparts. 
Taken altogether, the late Campanian-Maastrichtian palynological assemblages from northern and eastern Iberia suggest the co-existence of various types of wind-pollinated plant communities. Fagales represented a significant proportion of the local vegetation and could either incorporate exclusively Normapolles-producing plants (Chera, Lo Hueco) or plants with modern affinities (Molí de Baró-1) or a mix of the two groups (Barranco de la Posa). Conifers may have formed another component of windpollinated communities with regional significance as bisaccate pollen grains dominated some assemblages at Lo Hueco (Bascuña Member, Villalba de la Sierra Formation; Peyrot et al., 2013), Isona (Tremp Group, sample ISP-2 in Villalba-Breva et al., 2015 and samples V2B, V3B and V5B in Torices et al., 2012) and elsewhere in SW Europe (Médus et al., 1992). While the spatial distribution of conifer stands and their exact relationship with other arborescent communities remain uncertain, the marked signature of pollen assemblages seems to indicate plant communities with distinct composition forming a mosaic regional flora. This interpretation is coherent with and has probably been promoted by the highly fragmented paleogeographic context of Iberia and Western Europe (Csiki-Sava et al., 2015).

The assemblages from Chera lack the typical Normapolles characterizing the palynofloras of Northern and Central Europe (Goczán et al., 1967; Batten, 1984;

\subsection{Correspondence with plant macroremains}

The palynoflora from Chera can also be related to plant macroremains described in other Spanish Late Cretaceous outcrops (Villalba-Breva et al. 2012, 2015; Marmi et al., 
2015; Marmi, 2016). In Chera and other Iberian palynological successions, the abundance of monocolpate pollen related with Arecaceae would match well the megafloral assemblages of Isona incorporating the palm Sabalites and interpreted to represent a backswamp (Villalba-Breva et al., 2015). Palms have also been documented in assemblages from fluvial deposits (Marmi et al., 2015) probably representing riparian community. Altogether, this data suggest that palms were quite widespread and colonized distinct plant communities growing in wet environments.

While leaf macrorremains and floral mesofossils affiliated to Fagales have been reported in the European Late Cretaceous (see e.g, the occurrence of Dryophyllum in Ukrania [Vakhrameev, 1991] and flower remains in Portugal [Schönenberg et al., 2001; Friis et al., 2003, 2011]), the occurrence of macrofossils attributed to this group remains scarce in Spain. This result is surprising given the abundance of palynological data supporting their widespread occurrence in Spain (and Western Europe). This discrepancy could be related with the reduced transport capability of vegetative remains when compared with miospores. It also confirms that Normapolles producers were colonizing areas where accumulation and preservation of organic matter were not favored.

It is difficult to attribute dicotyledon leaf remains from Late Cretaceous phyllocoenosis to a determinate taxonomical order. However, the occurrence of specimens of Alnophyllum and Betuliphyllum could indicate the presence of Fagales in the lower Maastrichtian Isona outcrop (southeastern Pyrenees; Marmi, 2016).

The presence of Cheirolepidiaceae in Campanian-Maastrichtian strata from Spain (Villalba-Breva et al., 2012, 2015) remain still not supported by palynological data obtained from Chera and elsewhere in Spain.

\section{Conclusions}

1. The vertebrate-bearing site of Chera can be dated as late Campanian/?early Maastrichtian on the basis of several terrestrial markers. The lack of reliable marine marker does not allow to independently confirm this biostratigraphic inference.

2. The productive palynofloral assemblages indicate different environments of depositions and surrounding vegetations. 
3. The presence of wetlands with ephemeral or semi-permanent pools and lakes colonized by a vegetation involving peat-mosses, sedges and palms can be inferred by a clear palynological signal which has not been recorded in other Cretaceous successions from Spain.

4. Normapolles-producers and more evolved Fagales colonised driest hinterlands and formed part of woodlands and/or other open vegetation types.

5. Different types of wetlands and associated lowland vegetations co-existed in Spain during the Cretaceous and included freshwater and brackish ones.

\section{Acknowledgements}

This work is a contribution of the research project CRE: "Cretaceous Resin Event:

Global bioevent of massive resin production at the initial diversification of modern

\section{Bibliography}

Alonso, A., Meléndez, N., Mas, J.R., 1991. Sedimentación lacustre durante el Cretácico en la Cordillera Ibérica, España. Acta Geológica Hispánica 26, 35-54.

Alpert, P., 2005. The Limits and Frontiers of Desiccation-Tolerant Life. Integrative and Comparative Biology 45, 685-695.

Angiosperm Phylogeny Group, 2016. An update of the Angiosperm Phylogeny Group classification for the orders and families of flowering plants: APG IV. Botanical Journal of the Linnean Society. 181, 1-20.

Ashraf, A.R., Erben, H.K., 1986. Palynologische Untersuchungen an der Kreide/TertiärGrenze west-mediterraner Regionen. Palaeontographica Abteilung B 200, 111163.

Assadollahi, F., Barbéro, M., Quézel, P., 1982. Les écosystèmes préforestiers et forestiers de l'Iran. Ecologia Mediterranea 8, 365-373. 
Barrón, E., Postigo-Mijarra, J.M., Casas-Gallego, M., 2016. Late Miocene vegetation and climate of the La Cerdanya Basin (eastern Pyrenees, Spain). Review of Palaeobotany and Palynology 235, 99-119.

Batten, D.J., 1984. Palynology, climate and the development of Late Cretaceous floral provinces in the Northern Hemisphere; a review. In: Brenchley, P.J. (Ed.), Fossils and Climate. John Wiley \& Sons, Chichester, pp. 127-164.

Batten, D.J., 1986a. The Cretaceous Normapolles pollen genus Vancampopollenites: occurence, form, and function. Special Papers in Palaeontology 35, 21-39.

Batten, D.J., 1986b. Possible functional implications of exine sculpture in some Late Cretaceous Normapolles pollen. In: Blackmore, S., Ferguson, I.K. (Eds.), Pollen and spores: form and function. Academic Press, London, pp. 219-232.

Batten, D.J., 1996a. Palynofacies and petroleum potential. In: Jansonius, J., McGregor, D.C. (Eds.), Palynology: principles and applications. American Association of Stratigraphic Palynologists Foundation, Dallas, pp. 1065-1084.

Batten, D.J., 1996b. Upper Jurassic and Cretaceous miospores. In: Jansonius, J., McGregor, D.C. (Eds.), Palynology: principles and applications. American Association of Stratigraphic Palynologists Foundation, Dallas, pp. 807-830.

Batten, D.J., 1999. Small palynomorphs. In: Jones, T.P., Rowe, N.P. (Eds.), Fossil plants and spores: modern techniques. Geological Society, London, pp. 15-19.

Batten, D.J., Christopher, R.A., 1981. The Normapolles group and province. Review of Palaeobotany and Palynology 35, 131-137.

Batten, D.J., Li, W., 1987. Aspects of palynomorph distribution, floral provinces and climate during the Cretaceous. Geologisches Jahrbuch Reihe A 96, 219-237.

Batten, D.J., Morrison, L., 1987. Morphology and occurrence of the Normapolles pollen genus Papillopollis in the Cretaceous of Portugal. Palynology 11, 133-154.

Batten, D.J., Dupagne-Kievits, J., Lister, J.K., 1988. Palynology of the Upper Cretaceous Aachen Formation of Northeast Belgium. In: Streel, M., Bless, M.J.M. (Eds.), The Chalk District of the Euregio Meuse-Rhine pp. 95-103.

Casas-Gallego, M., 2018. Estudio palinológico del Oligoceno-Mioceno Inferior de la Cuenca de As Pontes (Galicia, España). Publicaciones del Instituto Geológico y Minero de España, Serie: Tesis Doctorales 31, 1-556.

Company, J., 2004. Vertebrados continentales del Cretácico Superior (CampanienseMaastrichtiense) de Valencia. Tesis doctoral, Universitat de València, 410 pp. [Unpublished]. 
Company, J., 2011. Bone histology of the titanosaur Lirainosaurus astibiae (Dinosauria: Sauropoda) from the latest Cretaceous of Spain. Naturwissenschaften, 98, 67-78.

Company, J., Pereda-Suberbiola, X., Ruiz-Omeñaca, J. I., Buscalioni, A. D., 2005. A new species of Doratodon (Crocodyliformes: Ziphosuchia) from the Late Cretaceous of Spain. Journal of Vertebrate Paleontology, 25: 343-353.

Company, J., Pereda Suberbiola, X., Ruiz-Omeñaca, J.I., 2009a. Los dinosaurios del Cretácico Terminal del Levante ibérico en el contexto paleogeográfico europeo. Composición de las faunas e implicaciones paleobiogeográfica. In Actas de las IV Jornadas Internacionales sobre Paleontología de Dinosaurios y su Entorno, Salas de los Infantes (Burgos), pp. 17-44.

Company, J., Szentesi, Z., Makádi, L., 2009b. Amphibians and lizards from the Upper Cretaceous (Late Campanian - Early Maastrichtian) Sierra Perenchiza Formation (Valencia Province, Spain). Abstract Volume of the 7th Annual Meeting of the European Association of Vertebrate Palaeontologists, Berlin: p. 20.

Company, J., Szentesi, Z., 2012. Amphibians from the Late Cretaceous Sierra Perenchiza Formation of the Chera Basin, Valencia Province, Spain. Cretaceous Research 37, 240-245.

Corral, J.C., Pueyo, E.L., Berreteaga, A., Rodríguez-Pintó, A., Sánchez, E., PeredaSuberbiola, X., 2016. Magnetostratigraphy and lithostratigraphy of the Laño vertebrate-site: Implications in the uppermost Cretaceous chronostratigraphy of the Basque-Cantabrian Region. Cretaceous Research 57, 473-489.

Costa Tenorio, M., Morla Juristi, C., Sainz Hollero, H. (Eds.), 2005. Los bosques ibéricos: una interpretación geobotánica. Ed. Planeta, Barcelona, 4th ed. 597 pp.

Crane, P., Lidgard, S., 1989. Angiosperm diversification and palaeolatitudinal gradients in Cretaceous floristic diversity. Science 246, 675-678.

Csiki-Sava, Z., Buffetaut, E., Ösi, A., Pereda-Suberbiola, X., Brusatte, S.L. (2015): Island life in the Cretaceous - faunal composition, biogeography, evolution, and extinction of land-living vertebrates on the Late Cretaceous European archipelago. Zookeys 469, 1-161.

Diéguez, C., Peyrot, D., Barrón, E., 2010. Floristic and vegetational changes in the Iberian Peninsula during Jurassic and Cretaceous. Review of Palaeobotany and Palynology 162, 325-340.

Farabee, M.J., Canright, J.E., 1986. Stratigraphic palynology of the lower part of the 
Lance Formation (Maastrichtian) of Wyoming. Palaeontographica Abteilung B $199,1-89$.

Fernández-Marrón, M.T., López-Martínez, N., Fonollá-Ocete, J.F., Valle-Hernández, M.F., 2004. The palynological record across the Cretaceous-Tertiary boundary on differing palaeogeographical settings from the southern Pyrenees, Spain. In: Beaudoin, A.B., Head, M.J. (Eds.), The palynology and Micropalaeontology of Boundaries, 230. Geological Society of London, pp. 243-255. Special Publication.

Frederiksen, N.O., 1995. Differing Eocene floral histories in Southeastern North America and Western Europe : influence of Paleogeography. Historical Biology $10,13-23$.

Friis, E.M., Pedersen, K.R., Schönenberger, J., 2003. Endressianthus, a new Normapolles-producing plant genus of Fagalean affinity from the Late Cretaceous of Portugal. International Journal of Plant Sciences 164, 201-223.

Friis, E.M., Crane, P.R., Pedersen, K.R., 2011. Early flowers and angiosperm evolution. Cambridge University Press, Cambridge, 585 pp.

García, A., Mas, R., Segura, M., Carenas, B., García-Hidalgo, J.F., Gil, J., Alonso, A., Aurell, M., Bádenas, B., Benito, M.I., Meléndez, A., Salas, R. (2004): Capítulo 5 Cordilleras Ibérica y Costero-Catalana. 5.3.4. Segunda fase de post-rifting: Cretácico Superior. In: J. Vera (ed.), Geología de España. Sociedad Geológica de España - Instituto Geológico y Minero de España: 510-522.

Góczán, F., Groot, J. J., Krutzsch, W., Pacltová, B. (1967). Die Gattungen des “Stemma Normapolles Pflug 1953b" (Angiospermae). Paläontologische Abhandlungen, Abteilung B, Paläobotanik 2 (2-3), 427-633.

Gruas-Cavagnetto, C., 1968. Étude palynologique des divers gisements du Sparnacien du Bassin de Paris. Mémoires de la Société Géologique de France 47, 4-144.

Handy, M.R., Schmid, S.M., Bousquet, R., Kissling, E., Bernoulli, D. 2010. Reconciling plate-tectonic reconstructions of Alpine Tethys with the geologicalgeophysical record of spreading and subduction in the Alps. Earth-Science Reviews 102, 121-158.

Heimhofer, U., Wucherpfennig, N., Adatte, T., Schouten, S., Schneebeli-Hermann, E., Gardin, S., Keller, G., Kentsch, S., Kujau, A., 2018. Vegetation response to exceptional global warmth during Oceanic Anoxic Event 2. Nature Communications 9, 3832. DOI: 10.1038/s41467-018-06319-6. 
Herngreen, G.F.W., Felder, W.M., Kedves, M., Meessen, J.P.M.T., 1986. Micropaleontology of the Maastrichtian in Borehole Bunde, The Netherlands. Review of Palaeobotany and Palynology 48, 1-70.

Herngreen, G.F.W., Kedves, M., Rovnina, L.V., Smirnova, S.B., 1996. Chapter 29C. Cretaceous palynofloral provinces: a review. In: Jansonius, J., McGregor, D.C. (eds.), Palynology: principles and applications. American Association of Stratigraphic Palynologists Foundation, vol. 3, 1157-1188.

Jacobson, G.L., Bradshaw, R.H.W., 1981. The selection of sites for paleovegetational studies. Quaternary Research 16, 80-96.

Jardiné, S., Magloire, L., 1965. Palynologie et Stratigraphie du Crétacé des bassins du Sénégal et de Côte d'Ivoire. Mémoire du Bureau Recherche Géologie Minière 32, $187-245$.

Kedves, M., 1985. The present-day state of Upper Cretaceous palaeophytogeography on Palynological evidence. Acta Biologica, Szeged 31, 115- 27.

Kedves, M., Pittau, P., 1979. Contributions à la connaissance des pollens des Normapolles du "groupe papilloide" du crétacé supérieur du Portugal. Pollen et Spores 21, 169-209.

Kedves, M., Herngreen, G.F.W., 1980. Palynology of the stratotype of the Maestrichtian and the Gulpen Formation, ENCI section, Maastrich, The Netherlands. Pollen et Spores 22 (3-4), 483-544.

Kedves, M., Russell, D.E., 1982. Palynology of the Thanetian layers of Menat. Palaeontographica Abteilung B 182, 87-150.

Korasidis, V.A., Wagstaff, B.E., Gallagher, S.J., Duddy, I.R., Tosolini, A.-M.P., Cantrill, D.J., Norvick, M.S., 2016. Early angiosperm diversification in the Albian of southeast Australia: implications for flowering plant radiation across eastern Gondwana. Review of Palaeobotany and Palynology 232, 61-80.

Krutzsch, W., Mibus, I., 1973. Sporenpaläontologischer Nachweis von kontinentalem Maastrich in Walbeck (Bezirk Magdeburg, DDR). Abhandlunger Zentralblatt für geologie Institut 18, 99-108.

Legoux, O., 1986. Nouvelles observations sur le genre Pseudoromeinipollenites Kedves. Pollen et Spores 27, 413-418.

Marmi, J., 2016. Taxonomic revision of the J. Vicente collection dicotyledon leaves from the lower Maastrichtian of Isona (northeastern Iberia). Treballs del Museu de Geologia de Barcelona 22, 57-100. 
Marmi, J., Martín-Closas, C., Fernández-Marrón, M.T., Fondevilla, V., Gomez, B., 2015. A riparian plant community from the upper Maastrichtian of the Pyrenees (Catalonia, NE Spain). Cretaceous Research 56, 510-529.

Mayr, C., Thümmler, B., Windmaier, G., Altenbach, A.V., Köhler, H., Tiedemann, R. 1999. New data about the Maastrichtian/Danian transition in the Southern Pyrenees (Ager Basin, Catalonia, Spain). Revista Española de Micropaleontología $31(3), 357-368$.

Médus, J., 1981. Pollen Normapolles de coupes stratotypiques du Crétacé Supérieur des Charentes et du Sénonien du Portugal. Comunicações dos Serviços Geológicos de Portugal 67, 19-28.

Médus, J., 1987. Analyse quantitative des palynoflores du Campanien de Sedano, Espagne. Review of Palaeobotany and Palynology 51, 309-326.

Médus, J., Feist, M., Rocchia, R., Batten, D. J., Boclet; D., Colombo, F., Tambareau, Y., Villatte, J., 1988. Prospects for recognition of the palynological Cretaceous/Tertiary boundary and an iridium anomaly in nonmarine facies of the eastern Spanish Pyrenees: a preliminary report. Newsletter on Stratigraphy 18(3), $123-138$.

Médus, J., Colombo, F., Durand, J.P., 1992. Pollen and spore assemblages of the uppermost Cretaceous continental formations of south-eastern France and northeastern Spain. Cretaceous Research 13, 119-132.

Méon, H., 1991. Etudes spororpolliniques à la limite Crétacé-Tertiaire: La coupe du Kef (Tunisie Nord-Occidentale); Etude systématique, stratigraphie, paléogéographie et évolution climatique. Palaeontographica Abteilung B 223, 107-168.

Méon, H., Odin, G.S., Antonescu, A., Siegl-Farkas, A., 2001. Synthetic data on spores and pollen across the Campanian-Maastrichtian boundary at Tercis les bains (SW France). In: Odin, G.S. (Ed.), The Campanian-Maastrichtian Boundary. Elsevier Science, pp. 210-216.

Morin, N. R. (ed.), 1997. Flora of North America editorial committee. Magnoliophyta: Magniliidae and Hamamelidae, vol. 3. Oxford, New York, 614 pp.

Ollivier-Pierre, M.-F., Gruas-Cavagnetto, C., Roche, E., Schuler, M., 1987. Elements de flore de type tropical et variations climatiques au Paleogene dans quelques Bassins d'Europe Nord-Occidentale. Mémoires et Travaux de l'Institut de Montpellier, Ecole Pratique des Hautes Etudes 17, 173-205.

Ortega, F., Bardet, N., Barroso-Barcenilla, F., Callapez, P.M., Cambra-Moo, O., 
Daviero-Gómez, V., Díez Díaz, V., Domingo, L., Elvira, A., Escaso, F., GarcíaOliva, M., Gomez, B., Houssaye, A., Knoll, F., Marcos-Fernández, F., Martín, M., Mocho, P., Narváez, I., Pérez-García, A., Peyrot, D., Segura, M., Serrano, H., Torices, A., Vidal, D., \& Sanz, J.L., 2015. The biota of the Upper Cretaceous site of Lo Hueco (Cuenca, Spain). Journal of Iberian Geology 41 (1), 83-99.

Pereda-Suberbiola, X., Corral, J.C., Astibia, H., Badiola, A., Bardet, N., Berreteaga, A., Buffetaut, E., Buscalioni, A.D., Cappetta, H., Cavin, L., Díez Díaz, V., Gheerbrant, E., Murelaga, X., Ortega, F., Pérez-García, A., Poyato-Ariza, F., Rage, J. C., Sanz, J. L., Torices, A., 2015. Late Cretaceous continental and marine vertebrate assemblages of the Laño Quarry (Basque-Cantabrian Region, Iberian Peninsula): An update. Journal of Iberian Geology 41(1), 101-124.

Peyrot, D., Barrón, E., Comas-Rengifo, M.J., Thouand, E., Tafforeau, P., 2007. A confocal laser scanning and conventional wide field light microscopy study of Classopollis from the Toarcian-Aalenian of the Fuentelsaz section (Spain). Grana $46,217-226$.

Peyrot, D., Barrón, E., Comas-Rengifo, M.J., Barroso-Barcenilla, F., Feist-Burkhardt, S., 2008. Palinología del tránsito Cenomaniense/Turoniense en la sección de Puentedey (Burgos, España). Coloquios de Paleontología 58, 101-161.

Peyrot, D., Company, J., Barrón, E., 2009. Palynological data of the late Cretaceous vertebrate site of Chera (Southwestern Iberian Range, Valencia Province). Tenth International Symposium on Mesozoic Terrestrial Ecosystems and Biota, Teruel, pp. 127-128.

Peyrot, D., Barroso-Barcenilla, F., Cambra-Moo, O., 2013. Palaeoecology of the late Campanian/early Maastrichtian Fossil-Lagerstätte of "Lo Hueco" (Cuenca, Spain): Palynological insights. Palaeogeography, Palaeoclimatology, Palaeoecology 387, 27-39.

Platt, N. H., 1989. Lacustrine carbonates and pedogenesis: sedimentology and origin of palustrine deposits from the Early Cretaceous Rupelo Formation, W Cameros Basin, N Spain. Sedimentology, 36, 665-684.

Platt, N. H., Wright, V. P., 1992. Palustrine Carbonates and the Florida Everglades: towards an exposure index for the fresh-water environment? Journal of Sedimentary Petrology 62, 1058-1071.

de Porta, J., Kedves, M., Solé de Porta, N., Civis, J., 1985. Palinología del Maastrichtiense del Barranco de la Posa (Lérida, España). Problemática regional. 
Polette, F., Batten, D.J., 2017. Fundamental reassessment of the taxonomy of five Normapolles pollen genera. Review of Palaeobotany and Palynology 243, 47-91.

Pueyo, E.L., Pereda Suberbiola, X., Company, J., Sánchez, E., Berreteaga, A., Corral, J.C., 2014. Magnetostratigraphy of the latest Cretaceous vertebrate-bearing sites from the Basque-Cantabrian Region and eastern Iberian Range: Preliminary data. In Marmi, J., Oms, O., Vila, B., Galobart, À., Estrada, R., Dinarès-Turell, J. (Eds.), Reconstructing the Terrestrial End-Cretaceous Palaeoenvironments in Europe, Tremp, September 16-20th 2014, Field Trip Guide and Abstracts Book. Paleontologia i Evolució Memòria especial 7, p. 76.

Quézel, P., Barbéro, M., Akman, Y., 1980. Contribution à l'étude de la végétation forestière d'Anatolia septentrionale. Phytocoenologia 8 (3-4), 365-519.

Regali, M.S.P., Uesugui, N., Santos, A.S. 1974a. Palinologia dos sedimentos MesoCenozóicos do Brasil I. Boletim Técnico da Petrobrás, 17: 177-191.

Regali, M.S.P., Uesugui, N., Santos, A.S. 1974b. Palinologia dos sedimentos MesoCenozóicos do Brasil II. Boletim Técnico da Petrobrás, 17: 263-301.

Schönenberg, J., Pedersen, K.R., Friis, E.M., 2001. Normapolles flowers of fagalean affinities from the Late Cretaceous of Portugal. Plant Systematics and Evolution 226, 205-230.

Schrank, E., 1994. Palynology of the Yesomma Formation in northern Somalia: A study of pollen, spores and associated phytoplankton from the Late Cretaceous Palmae Province. Palaeontographica Abteilung B 231, 63-112.

Seton, M., Gaina, C., Müller, R.D., Heine, C., 2009. Mid-Cretaceous seafloor spreading pulse: Fact or fiction? Geology 37, 687-690.

Smith, A.G., Smith, D.G., Funnell, B.M., 1994. Atlas of Mesozoic and Cenozoic Coastlines. Cambridge University Press, Cambridge, 99 pp.

Sweet, A.R., 1986. The Cretaceous-Tertiary boundary in the central Alberta foothills. II: Miospore and pollen taxonomy. Canadian Journal of Earth Sciences 23, 13751388.

Torices, A., Fernández-Marrón, M.T., Fonollá, F., López-Martínez, N., 2012. Palynological characterization of a transgressive episode in transitional deposits in the Cretaceous Aren and Tremp formations (sout-central Pyrenees, Spain). Neues Jarbuch für Geologie und Paläontologie Abhandlungen 266 (2), 159-172.

Vakhrameev, V.A., 1991. Jurassic and Cretaceous Floras and Climates of the Earth. 
Cambridge University Press, Cambridge, 318 pp.

Van Itterbeeck, J., Markevich, V.S., Codrea, V., 2005. Palynostratigraphy of the Maastrichtian dinosaur- and mammal sites of the Râul Mare and Barbat Valleys (Hațeg Basin, Romania). Geologica Carpathica 56 (2), 137-147.

Vilas, L., Mas, R., García, A., Arias, C., Alonso, A., Meléndez, N., Rincón, R. (1982): Ibérica Suroccidental. In: A. García, (ed.), El Cretácico de España. Universidad Complutense de Madrid: 457-513.

Vajda-Santivanez, V., 1999. Miospores from Upper Cretaceous - Paleocene strata in northwestern Bolivia. Palynology 23, 181-196.

Villalba-Breva, S., Martín-Closas, C., Marmi, J., Gomez, B., Fernández-Marrón, M.T. (2012). Peat-forming plants in the Maastrichtian coals of the Eastern Pyrenees. Geologica Acta 10 (2), 189-207.

Villalba-Breva, S., Marmi, J., Gomez, B., Daviero-Gomez, V., Martín-Closas, C., Fernández-Marrón, M.T., 2015. Plant taphonomy and palaeoenvironment from the Upper Cretaceous of Isona, Tremp Basin, southern Pyrenees, Catalonia, Spain. Cretaceous Research 54, 34-49.

Yi, S., Batten, D.J., 2002. Palynology of Upper Cretaceous (uppermost CampanianMaastrichtian) deposits in the South Yellow Sea Basin, offshore Korea. Cretaceous Research 23, 687-706.

Yi, Sangheon, Yi, Songsuk, Batten, D.J., Yun, H., Park, S.-J., 2003. Cretaceous and Cenozoic non-marine deposits of the Northern South Yellow Sea Basin, offshore western Korea: palynostratigraphy and palaeoenvironments. Palaeogeography, Palaeoclimatology, Palaeoecology 191, 15-44.

\section{Figure captions}

Figure 1 (Geol. settings and sections) 
A. Simplified map of Valencia province showing the location of the collecting sites in the vicinity of Chera village; B. Stratigraphic sections of the Barranco del Agua $(\mathrm{CH})$ and La Castellana (LC) sections (modified from Company, 2004).

\section{Figure 2 (plate 1)}

A-C. Spinidinium spp. sample CH-I-4b, sample CH-III-1-4; D. Botryococcus sp., sample CH-III-1b; E. Ovoidites sprigii, sample CH-III-1b; F. Ovoidites cf. ligneolus, sample CH-III-1b; G. Ovoidites sp. 1, sample CH-III-1b; H. Tetranguladinium conspicum, sample CH-III-1b; I-J. Protoellipsodinium fibratum, sample CH-III-1b; KL. Spicadinium cf. akidoton, sample CH-III-1b. Scale bar equals $10 \mu \mathrm{m}$.

\section{Figure 3 (quantitative data)}

Circular abundance diagrams of freshwater algae, spores, angiosperms and gymnosperms constituting the fertile palynomorph assemblages of Chera.

\section{Figure 4 (plate 2)}

A. Biretisporites cf. potoniei, sample CH-III-1b; B. Undulatisporites cf. velamentis, sample CH-III-1b; C. Zlivisporis reticulatus, sample CH-III-1b; D. Cingulatisporites levispeciosus, sample CH-I-4; E. Ischyosporites spp., sample CH-III-1b; F. Patellasporites tavaredensis, sample LC-I-5; G. Gabonisporis vigourouxii, sample CHIII-1b; H. Gabonisporis cristatus, sample CH-III-1b; I. Gabonisporis? sp. 1, sample CH-III-1b; J-K. Ancanthotriletes? trigonus, sample CH-III-1b; L. Polypodiaceoisporites verruspeciosus, sample CH-III-1b. Scale bar equals $10 \mu \mathrm{m}$.

\section{Figure 5 (Plate 3)}

A. Equisetosporites multicostatus, sample $\mathrm{CH}-\mathrm{III}-1 \mathrm{~b}$; B. E. patapscoensis, sample $\mathrm{CH}-$ III-1b; C. Penetetrapites inconspicuus, sample CH-III-1b; D-E. Dichastopollenites dunveganensis, sample CH-III-1b; F. Caprifoliipites cf. paleocenicus, sample CH-III1b; G-H. Monocolpopollenites sp. 1, sample CH-III-1b; I. Monocolpopollenites cf. reticulatus, sample CH-III-1b; J. Albertipollenites rosalindiae, sample CH-III-1b; K-L. Trudopollis parvotrudens, sample CH-III-1b; M. Papillopollis cf. aradensis, sample CH-III-1b; N-O. Pseudoromeinipollenites laevigatus new comb., sample CH-III-1b; $\mathbf{P}$. Rugulitriporites sp., sample CH-I-4; Q. Trudopollis sp., sample CH-I-4; R. Oculopollis minutus, sample LC-I-5; S. Oculopollis verrucosus, sample CH-III-1b; T. 
Triatriopollenites sp., sample LC-I-5; U. Rhoipites sp., sample CH-III-1b; V.

782 Gallaportapollenites? sp., sample CH-III-1b; W. Tetracolporites sp., sample CH-III-1b;

783 X-Y. Subtriporopollenites anulatus: X. Sample CH-III-1b; Y. Sample, LC-I-5; Z.

784 Plicapollis serta, sample CH-III-1b; AA. Vacuopollis orthopyramis, sample CH-I-4;

785 AB. Vacuopollis microconcavus, sample LC-I-5; AC. Subtriporopollenites cf. nanus, 786 sample CH-III-1b; AD-AE. Vancampopollenites spp.: AD. sample CH-I-4; AE. sample 787 CH-III-1b; AF-AG. Tetracolporopollenites cf. halimbaense: AF. Small specimen, 788 sample CH-III-1b; AG. Large specimen, sample CH-1b; AH. Tricolpites sp. 1, sample 789 CH-I-4; AI. Nudopollis terminalis, sample CH-3-1b. Scale bar equals $10 \mu \mathrm{m}$.

790

$791 \quad$ Figure 6 (Plate 4)

792 A. Simpsonipollis mullensis, sample CH-I-4; B. Interporopollenites proporus, sample 793 CH-I-4; C. Interporopollenites microporus, sample CH-III-1b; D-I. 794 Vancampopollenites? sp. 1, sample LC-5: D. Specimen in equatorial view; E. Specimen 795 polar view; F. specimens in tetrad; G-I. Specimen observed under light microscopy 796 (G) and 3-D rendering (H-I) based on Confocal Laser Scanning Microscopy; J. 797 Tricolpites synstriatus, sample CH-III-1b. Scale bar equals $10 \mu \mathrm{m}$. 

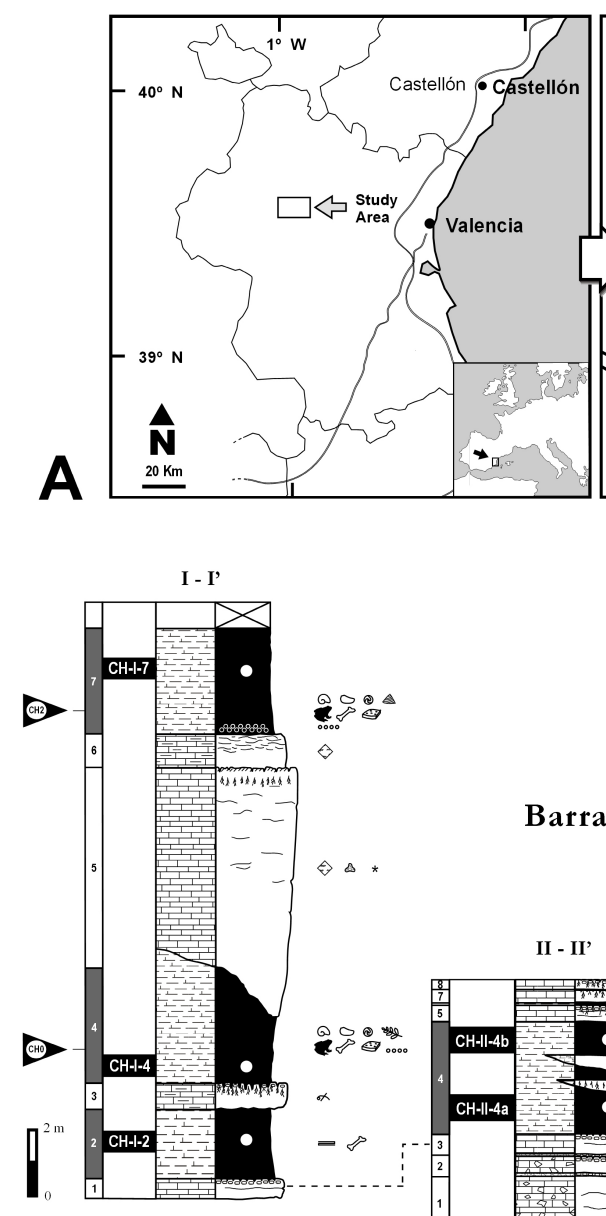

3 Sampled level

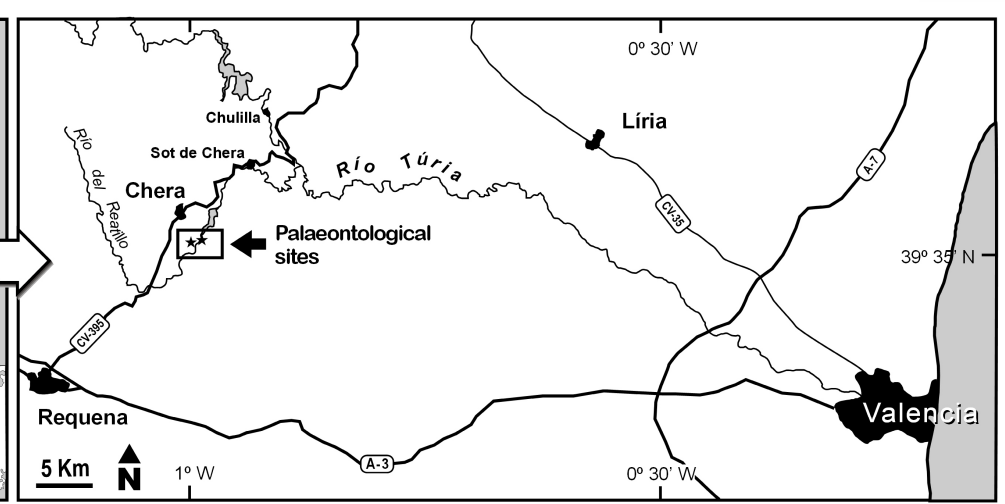

La Castellana Section (LC-)
Barranco del Agua Sections

(CH-)
LC-I-5 $\bullet$ Sample position

\begin{tabular}{|c|c|}
\hline \multicolumn{2}{|c|}{ LEGEND } \\
\hline 5 & Carbonate breccias \\
\hline 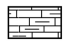 & Marly limestones \\
\hline 臣 & Carbonate mudstones-wakestones \\
\hline$=-1$ & Marly mudstones \\
\hline 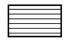 & Mudstones \\
\hline 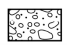 & Sandstones/conglomerates \\
\hline 0000 & Rip-up clasts \\
\hline इफ्षण & Pseudomicrokarst \\
\hline $0 \infty 0$ & Nodular surface \\
\hline 0000 & Carbonate glaebules \\
\hline$\ldots$ & Dark clasts \\
\hline 禹 & Geodes \\
\hline ஃ๐ & Gravel lenses \\
\hline$\equiv$ & Parallel lamination \\
\hline
\end{tabular}

Root casts

Haematitic concretions

$\Leftrightarrow \quad$ Mottling

$\approx$ Laminar carbonates

\&e Carbonized plant remains

* Indeterminate microfossils

(2) Charophytes

$\propto$ Indeterminate shell fragments

๑) Freshwater gastropods

$\checkmark$ Ostracodes

\section{F Foraminifers}

2 Microvertebrate remains

is Macrovertebrate remains

Eggshell fragments

(c) Macrovertebrate-bearing levels 

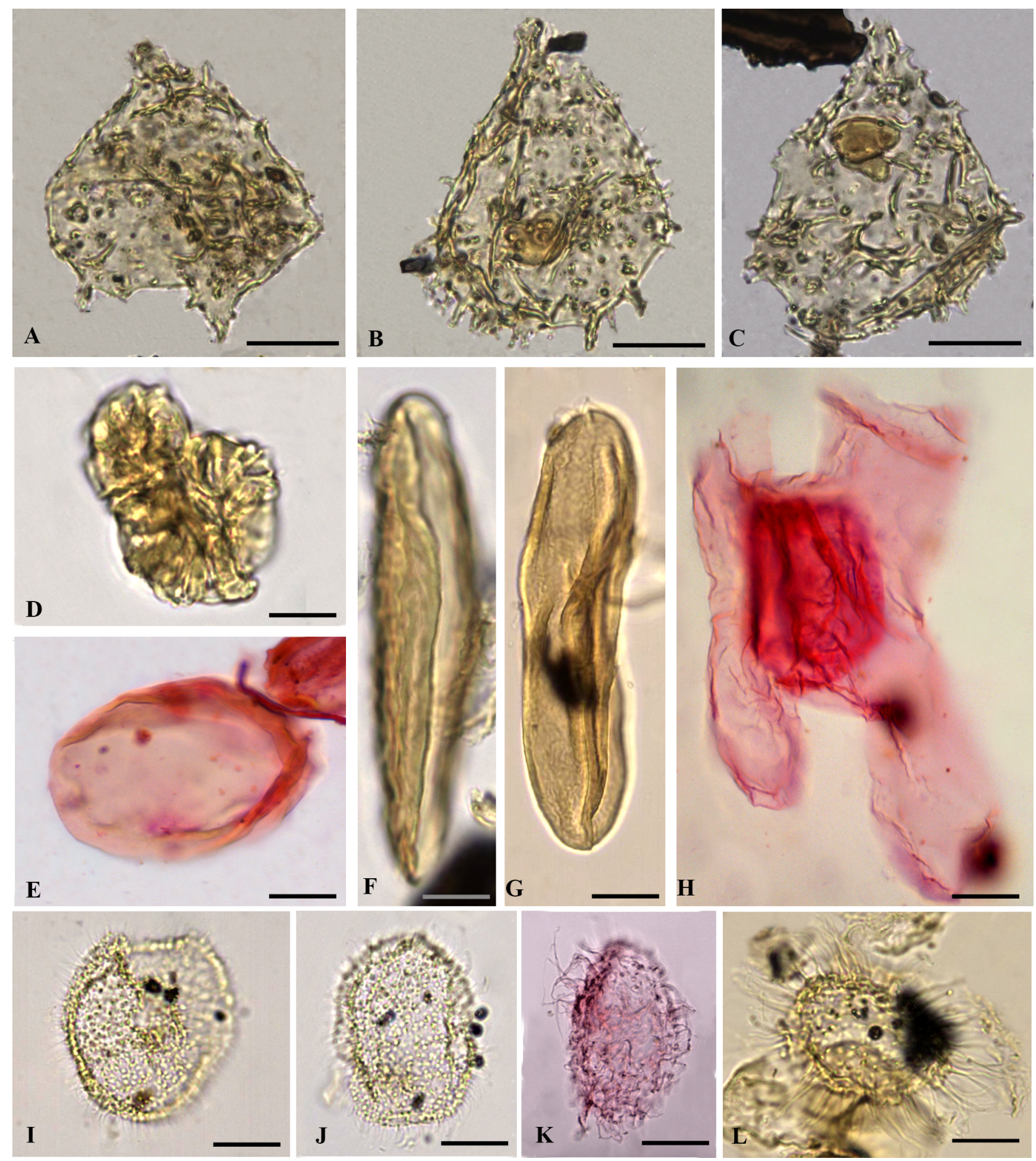

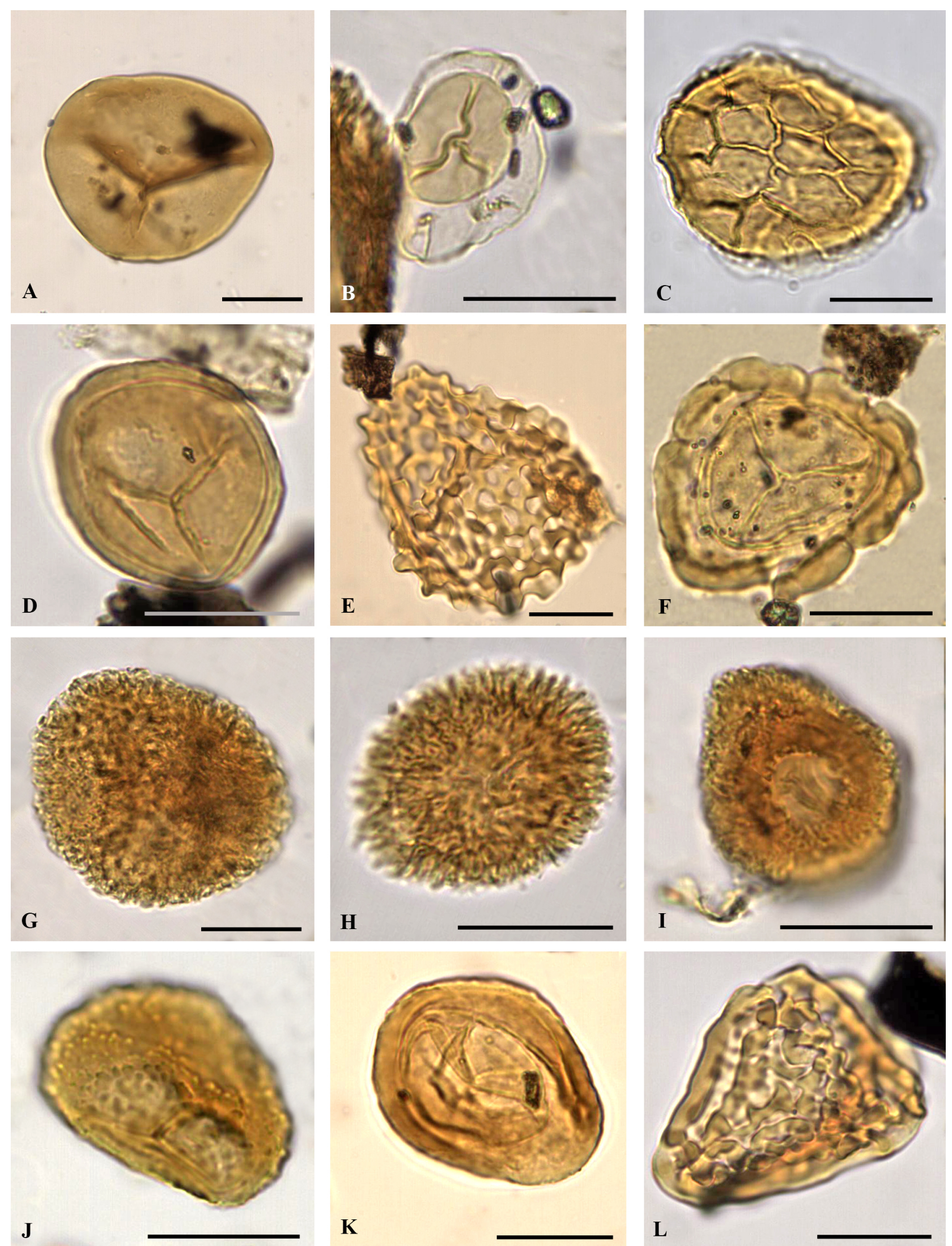

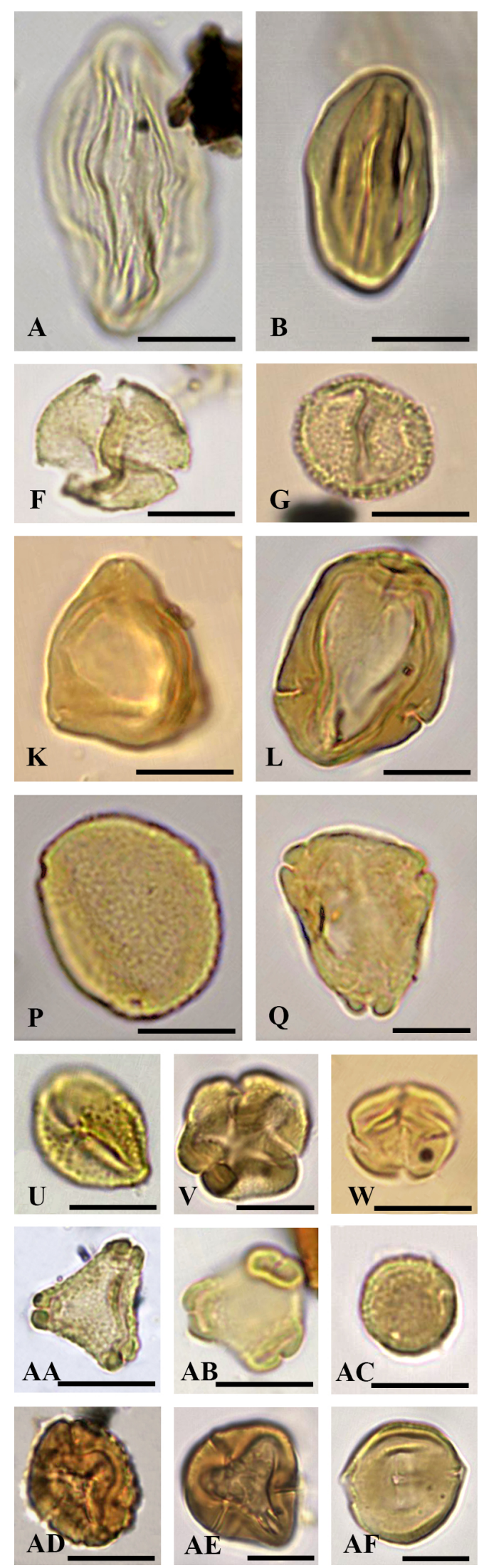
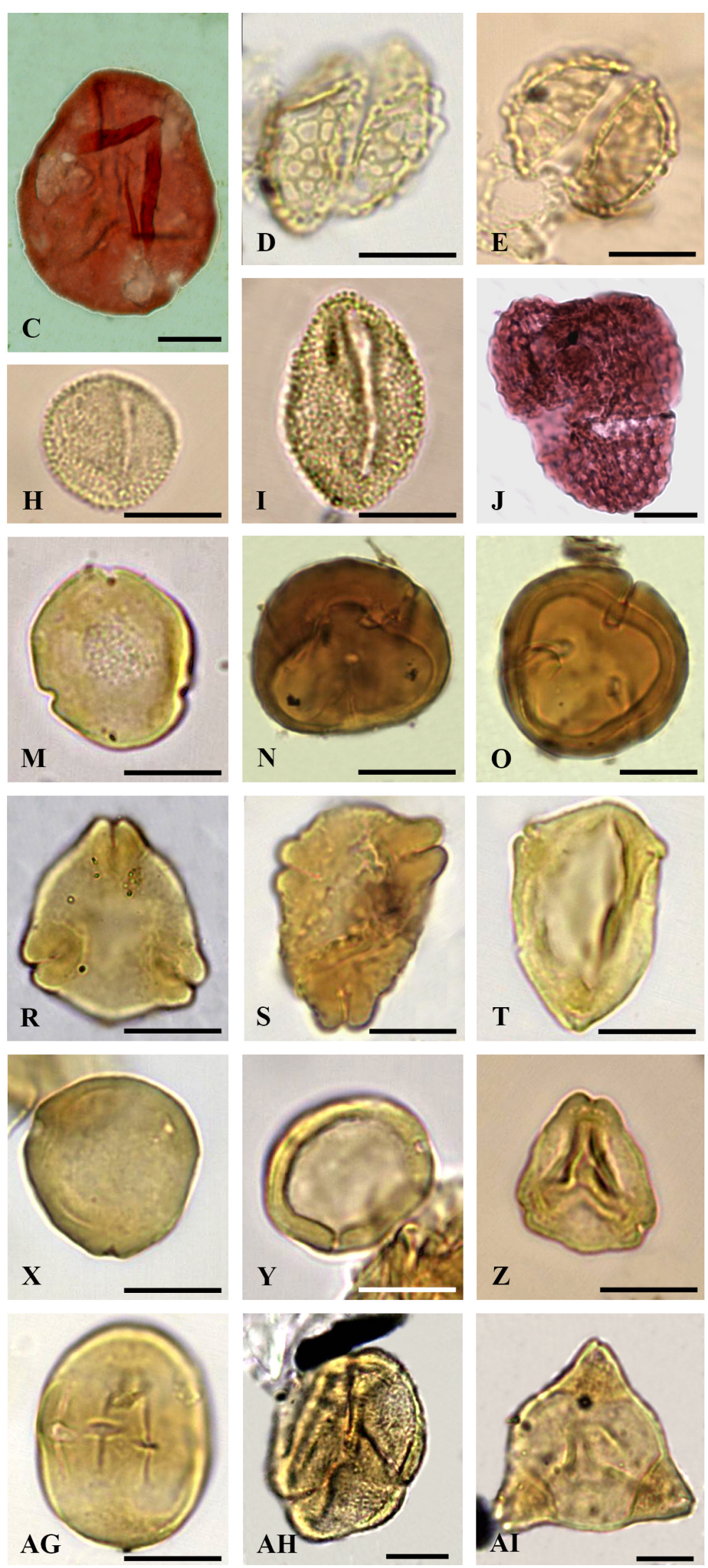
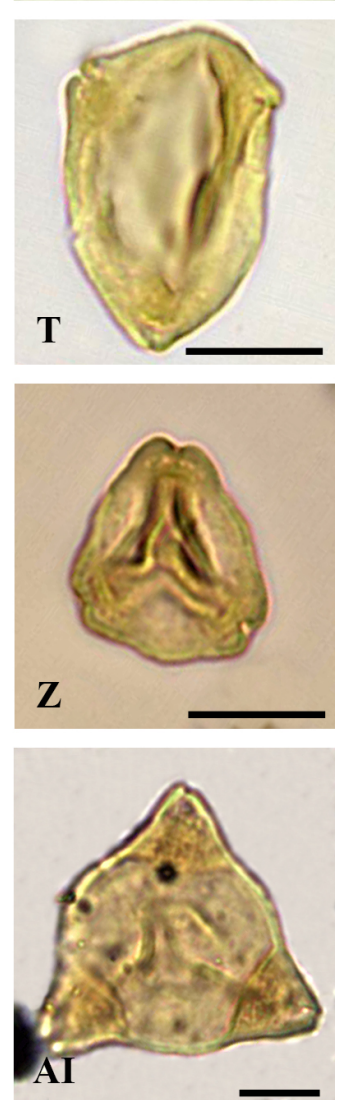

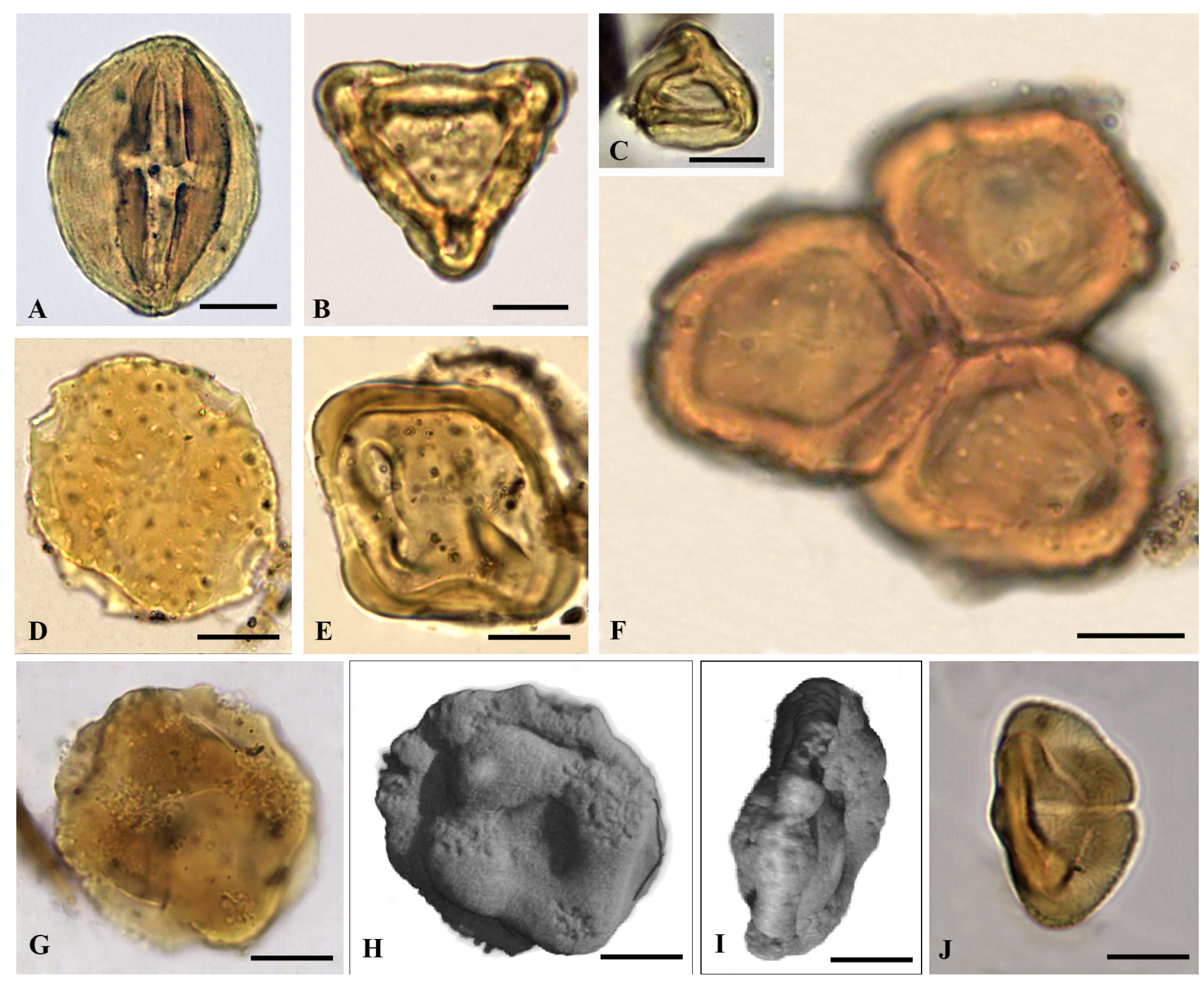